DOI: https://doi.org/10.47405/mjssh.v6i11.1168

\begin{tabular}{|c|c|}
\hline 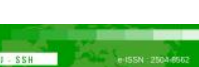 & Malaysian Journal of Social Sciences and Humanities (MJSSH) \\
\hline Malaysian Journal of & Volume 6, Issue 11, November 2021 \\
\hline (MJ-SSH) & e-ISSN : 2504-8562 \\
\hline & $\begin{array}{l}\text { Journal home page: } \\
\text { www.msocialsciences.com }\end{array}$ \\
\hline
\end{tabular}

\title{
Kemampuan Pemilikan Rumah dalam kalangan Belia di Batu Kurau, Perak
}

\author{
Norazmawati Md. Sani ${ }^{1}$, Nurul Shafiqah Mohd Nori ${ }^{1}$ \\ 1Pusat Pengajian Perumahan, Bangunan dan Perancangan, Universiti Sains Malaysia (USM), \\ 11800 USM, Pulau Pinang, Malaysia
}

Correspondence: Norazmawati Md. Sani (norazmawati@usm.my)

\begin{abstract}
Abstrak
Kemampuan memiliki rumah sendiri adalah berkait rapat dengan pelbagai faktor yang antaranya ialah faktor ekonomi dan faktor sosial. Peningkatan migrasi luar bandar ke kawasan Bandar menyebabkan berlakunya kenaikan harga rumah, pendapatan yang tidak mencukupi dan kos sara hidup yang tinggi yang telah menyebabkan golongan belia menghadapi masalah untuk memiliki rumah sendiri. Objektif kajian ini adalah untuk mengenal pasti tahap kemampuan golongan belia untuk memiliki rumah sendiri di Batu Kurau dan untuk mengkaji faktor-faktor yang mempengaruhi kemampuan golongan belia untuk memiliki rumah sendiri. Kajian ini menggunakan kaedah tinjauan dan soal selidik terhadap 85 orang responden yang dipilih secara rawak berdasarkan kriteria yang telah ditetapkan. Dapatan kajian dianalisis secara kuantitatif dengan menggunakan kaedah analisis kekerapan dan kaedah analisis deskriptif. Hasil kajian menunjukkan bahawa responden yang terdiri dari kalangan belia di Batu Kurau, Perak memiliki tahap sebenar kemampuan pemilikan rumah adalah hanya mampu memiliki rumah sendiri pada harga di bawah RM150,000 seunit. Manakala faktor-faktor utama yang mempengaruhi kemampuan golongan belia untuk memiliki rumah sendiri ialah faktor masalah kelayakan mendapatkan pinjaman perumahan, faktor bayaran wang pendahuluan yang tinggi semasa membeli rumah, faktor harga rumah yang mampu dimiliki tetapi tiada dalam pasaran perumahan serta faktor tanggungan bilangan anak yang ramai dan faktor tanggungan jumlah ahli keluarga yang ramai.
\end{abstract}

Kata kunci: kemampuan, pemilikan rumah, golongan belia, persampelan rawak, skim perumahan

\section{Housing Ownership among Youth at Batu Kurau, Perak}

\begin{abstract}
The ability to own a home is related to various factors, which are economic factors and social factors. The increase in rural to urban migration has led to rising house prices, insufficient income and high cost of living. The objective of this study is to identify the level of ability of youths to own a house in Batu Kurau and to study the factors that affect the ability of youths to own a house. This study uses a survey and questionnaire method on 85 respondents who were randomly selected based on the criteria that have been set. The findings of the study were analyzed quantitatively by using frequency analysis and descriptive analysis method. The results of the study showed that respondents from youths in Batu Kurau, Perak showed that the real level of home ownership ability is only able to own a house priced below RM150, 000 per unit. While, the main factors that affect the ability of youths to own a house are the factor of eligibility to obtain housing loan, the factor of high down payment, the factor of affordable house prices is not in the market and the factor of many children and big size of families.
\end{abstract}


Keywords: affordability, home ownership, youth, random sampling, housing scheme

\section{Pengenalan}

Setiap individu mempunyai angan-angan dan impian untuk memiliki dan membeli rumah sendiri bagi menjamin kehidupan yang lebih selesa dan lebih privasi bersama keluarga. Menurut Bujang (2006), keputusan untuk membeli rumah merupakan satu langkah yang amat besar dalam kehidupan seseorang kerana keputusan untuk membeli dan memiliki rumah sendiri bukan sahaja perlu untuk mengeluarkan belanja wang yang besar pada setiap bulan malahan juga merupakan pelaburan jangka panjang yang akan memberi pulangan dan faedah yang besar pada masa hadapan (Bujang, 2006).

Pemilikan rumah juga penting untuk setiap individu kerana rumah memberikan tempat untuk berlindung, berkumpul bersama ahli keluarga melakukan aktiviti harian dan menyediakan keselesaan kepada penghuni rumah. Rumah merupakan tempat berlindung dan keperluan asas yang paling utama yang perlu dipenuhi oleh seseorang sebelum memenuhi keperluan lain secara berperingkat. Isu kemampuan pemilikan rumah di Malaysia sering kali dibincangkan dan merupakan isu utama berkait dengan mereka yang tergolong dalam golongan berpendapatan rendah (B40) dan golongan berpendapatan pertengahan (M40). Pelbagai usaha telah dilakukan oleh kerajaan bagi menangani masalah ini bahkan kerajaan juga turut memberikan perhatian terhadap cabaran kos sara hidup rakyat yang saban hari semakin meningkat yang turut mempengaruhi pendapatan isi rumah ini.

Terdapat pelbagai definisi berkenaan kemampuan perumahan dan definisi asasnya adalah berkenaan dengan kemampuan pendapatan untuk menampung kos pembelian rumah. Bagi menentukan kemampuan perumahan seseorang, pendapatan isi rumah merupakan asas utama yang perlu ditentukan terlebih dahulu (Arimah, 1997). Menurut Norazmawati (2007) terdapat enam (6) pemboleh ubah utama yang dikenal pasti mempengaruhi kemampuan golongan berpendapatan rendah untuk memiliki rumah kos rendah ialah pendapatan isi rumah, perbelanjaan isi rumah, jenis-jenis pekerjaan, tahap pendidikan, isi rumah yang bekerja dan jumlah bayaran bulanan perumahan. Konsep kemampuan perumahan bertujuan untuk melihat keupayaan isi rumah untuk membayar ansuran rumah (Hulchanski, 1995). Pasaran perumahan juga turut mempengaruhi kemampuan perumahan kerana harga rumah untuk perkhidmatan perumahan mungkin melebihi harga purata pasaran perumahan (Thalmann, 2003). Keadaan ini akan menyebabkan golongan berpendapatan rendah tidak mampu untuk memiliki rumah sebaliknya terpaksa terus menyewa rumah sedia ada. Hal ini akan memberi kesan yang lebih kepada mereka yang tergolong dalam kumpulan yang berpendapatan rendah (B40).

\section{Sorotan Literatur}

Kenaikan harga rumah pada kadar yang lebih jauh yang melebihi pertumbuhan pendapatan sebenar yang dipengaruhi oleh pertumbuhan ekonomi negara yang kukuh sejak beberapa dekad lalu. Kenaikan harga rumah dalam pasaran telah menjejaskan kemampuan pemilikan rumah dalam kalangan masyarakat terutamanya golongan belia kerana mereka akan menghadapi masalah untuk membuat pembayaran balik pinjaman perumahan pada masa akan datang serta kenaikan kadar faedah yang tinggi. Sejak kebelakangan ini, isu kemampuan pemilikan rumah telah menjadi satu topik hangat sehingga mendapat perhatian daripada pemimpin politik dan pemimpin kerajaan lain kerana situasi ini akan memberikan kebimbangan kepada anggota masyarakat dan pemimpin kerajaan dan juga akan memberikan kesan kepada mereka yang memiliki pendapatan rendah dan sederhana. (Yates \& Gabriel, 2006).

Kebiasaannya, masalah dalam kemampuan untuk memiliki rumah kebanyakannya terdiri daripada mereka yang ingin membuat pembelian rumah pertama dan mencari rumah dengan harga yang mampu untuk dimiliki dengan pendapatan yang diperoleh. Dalam pada itu, rumah yang ingin dimiliki juga perlu lengkap dengan aspek keselamatan yang tinggi serta sesuai dengan keperluan dan kehendak 
bakal pembeli. Golongan belia terutamanya memiliki impian yang besar untuk memiliki rumah pada usia yang masih muda tetapi mereka masih dibelenggu dengan masalah kemampuan untuk memiliki rumah seperti masalah kewangan yang tidak mencukupi. Oleh itu, golongan belia sering mendapat perhatian berhubung dengan kemampuan mereka untuk memiliki rumah.

Kepesatan terhadap peningkatan populasi di Malaysia telah meningkatkan keperluan dan permintaan perumahan dalam kalangan rakyat. Pertumbuhan ini terjadi akibat peningkatan kadar kelahiran serta migrasi penduduk ke kawasan bandar yang kebanyakannya terdiri daripada golongan muda yang sedang mencari peluang pekerjaan. Senario ini seterusnya memberi pengaruh terhadap permintaan harta tanah perumahan bagi memenuhi keperluan asas rakyat dan penduduk. Oleh hal yang demikian, pembelian dan pemilikan rumah merupakan satu pelaburan besar.

\section{Faktor Makro Yang Mempengaruhi Kemampuan Pemilikan Rumah}

Faktor makro ialah faktor utama yang mempengaruhi setiap individu untuk membuat pembelian dan pemilikan rumah secara menyeluruh seperti faktor ekonomi, institusi kewangan, halangan dalam pinjaman, kos pinjaman, pembayaran balik pinjaman dan pendapatan.

\section{Faktor Ekonomi}

Pasaran harta tanah kini dilihat semakin meningkat naik yang didorong oleh beberapa faktor ekonomi seperti pendapatan, harga, ketersediaan kredit dan kadar faedah (Jemila \& Dietrich, 2006). Selain itu, perkembangan ekonomi negara juga turut menyebabkan sektor harta tanah negara berkembang pesat kebelakangan ini dan keadaan ini dapat dilihat melalui kepesatan pembangunan dalam sektor ekonomi yang menjana kenaikan pendapatan penduduk dan secara tidak langsung meningkatkan permintaan terhadap sektor perumahan. Perkara ini jelas menunjukkan bahawa permintaan terhadap pasaran perumahan berkadar lansung dengan pertumbuhan ekonomi negara. Oleh itu, kemampuan untuk memiliki rumah dalam kalangan rakyat dipengaruhi oleh kestabilan ekonomi negara.

\section{Institusi Kewangan}

Keputusan untuk membeli dan memiliki rumah turut dipengaruhi oleh institusi kewangan kerana fungsinya sebagai salah satu kemudahan yang akan dirujuk dalam pembelian rumah. Kemudahan untuk mendapatkan pinjaman daripada institusi kewangan swasta atau kerajaan ini menjadi penentu kepada pembelian rumah bagi menampung pembiayaan perumahan yang tinggi. Hal ini kerana, pembayaran deposit perumahan, pinjaman perumahan dan kadar faedah pinjaman turut dirangkumi dalam aspek pembiayaan perumahan. Hal ini merupakan inisiatif bagi membantu golongan belia dalam urusan pembelian rumah memandangkan mereka masih dalam keadaan yang belum stabil kerana masih baru dalam alam pekerjaan dan ada antara mereka yang masih mencari pekerjaan. Selain itu, kerana masih baru dalam dunia pekerjaan mereka juga menerima pendapatan yang rendah kerana tidak mempunyai pengalaman dan hal ini menyebabkan mereka sangat bergantung harap pada institusi kewangan untuk mendapatkan kemudahan pinjaman sekiranya mereka hendak membeli rumah.

Oleh itu, syarat-syarat yang ditetapkan oleh institusi kewangan perlu diikuti bagi setiap pemohon pinjaman di institusi kewangan. Bakal peminjam juga turut dilihat dari aspek berkenaan kelayakan mendapatkan pinjaman dan hal ini dikhuatiri mereka akan berdepan dengan kesukaran masalah bayaran pada masa hadapan sehingga menyebabkan rumah yang mereka memiliki itu akan dilelong dan hal ini akan meningkatkan kos kredit pada masa hadapan. Oleh itu, penelitian yang lebih terperinci perlu dilakukan terlebih dahulu terhadap pemilihan institusi kewangan dari segi prosedur, syarat pinjaman, kadar faedah yang dikenakan bagi memudahkan urusan dan proses mendapatkan kelulusan pinjaman yang dibuat oleh peminjam. 


\section{Halangan dalam Pinjaman}

Bakal pembeli rumah akan turut berhadapan dengan halangan untuk mendapatkan pinjaman sekiranya gagal mematuhi syarat-syarat yang telah ditetapkan oleh institusi kewangan malah mereka akan turut berhadapan dengan risiko permohonan pinjaman yang akan ditolak disebabkan pendapatan yang diterima tidak stabil dan rendah dan hal ini disebabkan mereka tidak memiliki pendapatan yang tetap. Permohonan untuk mendapatkan pinjaman akan turut berhadapan dengan kesukaran mendapatkan kelulusan pinjaman untuk pemohon yang hampir dengan umur persaraan. Hal ini kerana tempoh maksimum pinjaman ialah selama 30 tahun atau tidak melebihi had umur 60 tahun. Oleh itu, kelulusan pinjaman mempunyai hubung kait di antara harga dengan pendapatan bersih bulanan peminjam.

\section{Kos Pinjaman}

Bayaran dan faedah yang dikenakan ke atas pinjaman gadai janji yang merangkumi bayaran faedah, yuran pentadbiran dan yuran kemasukan dikenali sebagai kos pinjaman. Kadar faedah kadangkalanya mengalami kenaikan atau penurunan dan bergantung kepada keadaan ekonomi semasa dan kebiasaannya kadar faedah pinjaman akan mengalami kenaikan apabila keadaan ekonomi berada dalam keadaan tidak baik manakala semasa dalam keadaan ekonomi yang stabil, kadar faedah akan berlaku penurunan dan keadaan ini akan merangsang minat untuk membeli rumah dalam kalangan pembeli.

Kemudahan untuk mendapatkan pinjaman kewangan di Malaysia adalah berdasarkan Kadar Asas Pembelian Pinjaman (BLR) iaitu kadar faedah minimum yang dikenakan oleh institusi kewangan dengan mengambil kira kos institusi dan kos pentadbiran lain. Pelarasan yang dilakukan terhadap BLR dijalankan oleh pihak bank dengan kadar yang ditentukan oleh Bank Negara Malaysia (BNM) dalam mesyuarat dasar monetari. Walau bagaimanapun, BLR dijangka akan mengalami kenaikan atau penurunan dan hal ini akan memberikan kesan terhadap peningkatan dan pengurangan jumlah pembayaran semula dan akan memberi kesan terhadap tempoh pembayaran balik pinjaman. Namun, bermula 2 Januari 2015, pihak Bank Negara telah mengeluarkan arahan kepada pihak perbankan yang terdapat di Malaysia agar mereka menggunakan Kadar Asas (BR) bagi menggantikan BLR.

Di samping itu, seseorang yang ingin membeli rumah juga digalakkan untuk membuat pengeluaran daripada simpanan caruman Kumpulan Wang Simpanan Pekerja (KWSP) bagi membantu mengurangkan jumlah pinjaman daripada institusi kewangan dan hal ini sekali gus akan mengurangkan komitmen bayaran balik bulanan. Namun begitu, bagi golongan yang baru bekerja mereka juga mengalami kesukaran untuk berbuat demikian kerana baru bekerja dan jumlah caruman yang sedikit. Oleh itu, perubahan terhadap kadar faedah pinjaman akan memberi kesan terhadap jumlah pinjaman serta tempoh bayaran balik pinjaman dan hal ini sekali gus akan mempengaruhi kemampuan perumahan dalam kalangan belia.

\section{Pembayaran Balik Pinjaman}

Tempoh untuk membayar semula pinjaman bergantung kepada tempoh pembayaran balik yang dipohon oleh pembeli dan kebiasaannya 35 tahun merupakan tempoh maksimum pembayaran yang dihadkan atau tidak melebihi umur 70 tahun. Bagi pembeli rumah yang membuat tempoh pembayaran balik pinjaman dalam masa yang singkat terpaksa mengasingkan sebahagian besar pendapatannya untuk bayaran ansuran bulanan dan sebaliknya bagi mereka yang berpendapatan rendah, akan rasa terbeban dengan keadaan ini. Oleh yang demikian, golongan berpendapatan rendah dan sederhana biasanya mengharapkan pemanjangan tempoh pembayaran balik pinjaman kerana semakin panjang tempoh pembayaran balik pinjaman untuk membeli kediaman, maka semakin rendah bayaran ansuran bulanan yang perlu dibayar. Selain itu, aspek umur juga diambil kira oleh pihak bank dalam tempoh pembayaran balik pinjaman. Oleh yang demikian, golongan belia bumiputera dianggap beruntung sekiranya membeli rumah pada usia muda kerana berupaya menikmati tempoh panjang dalam pembayaran balik pinjaman. 


\section{Pendapatan}

Faktor pendapatan amat dititikberatkan dalam keputusan pembelian perumahan kerana melibatkan perbelanjaan terbesar sepanjang hayat. Pendapatan merujuk kepada keupayaan seseorang memasuki pasaran di samping bertindak sebagai pemacu kepada permintaan berkesan. Menerusi saiz relatif pendapatan, pengguna dapat menentukan saiz dan kualiti perumahan yang mampu dibeli. Maka, dengan kenaikan pendapatan golongan belia bumiputera akan mempengaruhi keupayaan isi rumah dalam menyediakan bayaran muka dan ansuran bulanan yang diperlukan.

\section{Faktor-Faktor Mikro Yang Mempengaruhi Pembelian Perumahan}

Faktor mikro pula berkaitan dengan ciri-ciri perumahan tersebut, profil dan demografi pembeli yang dianggap penentu kepada pembelian perumahan. Antara ciri-ciri perumahan yang sering diberi penekanan dalam pembelian perumahan adalah dari aspek lokasi, harga, kemudahsampaian, kemudahan awam dan kemudahan asas.

\section{Lokasi}

Aspek lokasi merupakan kriteria utama yang akan dipertimbangkan oleh bakal pembeli dalam pembelian perumahan. Lokasi lazimnya merujuk kepada tapak atau kawasan letakan sesuatu jenis harta tanah yang menentukan kedudukan harta tanah tersebut berada dalam kawasan bandar atau luar bandar serta dekat atau jauh dengan sesuatu pembangunan. Oleh yang demikian, pemilihan lokasi yang strategik sering menjadi kriteria utama dalam kalangan pembeli kerana menjimatkan masa dan kos perjalanan sama ada ke tempat kerja mahu pun ke pusat Bandar. Selain itu, lokasi yang strategik mempunyai kenaikan nilai pada masa hadapan. Bagi golongan belia bumiputera, mereka sangat menitikberatkan aspek lokasi yang berdekatan dengan pusat bandar dan tempat kerja kerana merasakan tinggal di pusat bandar berdekatan dengan pusat membeli-belah dan dilengkapi dengan pelbagai kemudahan selain menekankan aspek hiburan. Dengan itu, mereka dapat mengurangkan masa dan kos perjalanan untuk ke sesuatu destinasi.

\section{Harga}

Aspek harga sering menjadi pertimbangan utama dalam pembelian perumahan apabila melibatkan sejumlah besar pendapatan bulanan bakal pembeli. Maka, adalah penting untuk bakal pembeli membuat perbandingan harga perumahan di pasaran bagi mendapat gambaran mengenai anggaran harga rumah di pasaran terlebih dahulu bagi mengurangkan risiko kerugian pada masa hadapan. Peranan profesional penilai berdaftar dan ejen harta tanah amat diperlukan ketika ini bagi membuat analisis ke atas harta tanah subjek dengan harta tanah sebanding yang serupa di sekitarnya. Faktor harga ini turut menjadi penentu kepada kemampuan dan kesanggupan bakal pembeli dengan aspek kemampuan yang dimaksudkan itu akan diukur dari sudut pendapatan, jumlah simpanan yang ada, kemudahan kredit dan kadar faedah (Jemila \& Dietrich, 2006). Penentuan harga rumah ini dipengaruhi oleh letakan atau lokasi, aspek kemudahsampaian dan persekitaran perumahan yang ingin dibeli. Selain itu, faktor lain yang boleh dilihat menerusi letakan sesuatu kediaman tersebut berdekatan dengan pusat bandar, tempat kerja, pusat membeli-belah, sekolah dan rekreasi akan menyebabkan kenaikan nilai kediaman tersebut sebagai ganti rugi kepada kos perjalanan yang rendah. Harga perumahan pada hari ini dikatakan sedang melalui arus kenaikan dari tahun ke tahun ekoran kestabilan ekonomi negara. Keadaan ini boleh dilihat menerusi jadual Indeks Harga Rumah Nasional dari tahun 2000 hingga 2010 seperti pada Jadual 1.

Jadual 1: Indeks Harga Rumah Nasional (2000 - 2010)

\begin{tabular}{ccc}
\hline \multicolumn{3}{c}{ Indeks Harga Rumah Nasional } \\
\hline Tahun & $\begin{array}{c}\text { Indeks Harga Rumah } \\
\mathbf{2 0 0 0 = 1 0 0}\end{array}$ & \% Perubahan \\
\hline 2000 & 100 & 6.0 \\
\hline
\end{tabular}



DOI: https://doi.org/10.47405/mjssh.v6i11.1168

\begin{tabular}{lll}
\hline 2001 & 101.1 & 1.1 \\
2002 & 103.6 & 2.5 \\
2003 & 107.7 & 4.0 \\
2004 & 112.9 & 4.8 \\
2005 & 115.6 & 2.4 \\
2006 & 117.8 & 1.9 \\
2007 & 124.0 & 5.3 \\
2008 & 129.8 & 4.7 \\
2009 & 131.8 & 1.5 \\
2010 & 136.9 & 5.7 \\
2001 & 101.1 & 1.1 \\
\hline
\end{tabular}

Sumber: Pusat Maklumat Harta Tanah Negara (Napic), (2010)

Jadual 1 menunjukkan peningkatan harga rumah dari tahun 2000 sehingga 2010. Peningkatan harga rumah di pasaran berlaku dengan pesat sehingga tidak selari dengan pertumbuhan pendapatan isi rumah pada hari ini sekali gus menjejaskan pembelian perumahan. Oleh hal demikian, harga yang tinggi di pasaran ini telah mendorong golongan belia bumiputera untuk terus menyewa dari membuat pembelian kerana pendapatan mereka yang rendah tidak mampu menampung harga perumahan yang tinggi. Maka, adalah penting untuk golongan belia bumiputera membuat tinjauan ke atas harga perumahan di pasaran terlebih dahulu agar selari dengan pendapatan yang diterima bagi membolehkannya untuk membiayainya kelak.

\section{Kemudahsampaian}

Kemudahsampaian merujuk kepada jaringan dan rangkaian jalan raya atau laluan keluar dan masuk yang menghubungkan harta tanah kediaman dengan jalan utama bagi memudahkan pergerakan ke tempat lain. Faktor ini turut menjadi kriteria pilihan dalam pembelian perumahan kerana kediaman yang berdekatan dengan laluan keluar masuk yang sempurna memudahkan perhubungan di antara satu tempat ke satu tempat yang lain. Selain itu, letakkannya pada lapisan pertama dari jalan raya mewujudkan nilai yang tinggi apabila mereka bercadang untuk menjualnya di kemudian hari. Oleh itu, faktor kemudahsampaian turut dititikberatkan oleh golongan belia bumiputera kerana kemudahan akses yang baik berupaya memendekkan jarak dan menjimatkan masa perjalanan. Tambahan pula, golongan belia bumiputera ini sering disifatkan sebagai kurang sabar dan sentiasa mahu bergerak pantas menyebabkan mereka amat menekankan aspek masa perjalanan.

\section{Kemudahan Awam dan Kemudahan Asas}

Perumahan yang sering menjadi pilihan pembeli ialah perumahan yang dilengkapi dengan kemudahan awam dan asas yang sempurna agar perumahan tersebut dapat menjalankan fungsinya dengan baik dan selesa. Kemudahan merujuk kepada pelengkap kepada sesuatu kawasan perumahan yang selaras dengan Akta Perancangan Bandar dan Desa Malaysia, 1976 yang mendefinisikan kemudahan sebagai kualiti atau keadaan sesuatu kawasan yang menyumbang kepada keharmonian dan keseronokan yang lebih baik. Kemudahan awam dan asas yang dimaksudkan ialah sekolah, tempat ibadah, taman rekreasi, pusat kesihatan, balai polis, pasar raya dan sebagainya. Kebiasaannya, Golongan belia bumiputera gemar memilih perumahan yang berdekatan dengan pelbagai kemudahan seperti sekolah umpamanya kerana kebanyakan golongan belia bumiputera mempunyai anak kecil yang bersekolah menyebabkan perlunya mereka menghantar anak tersebut ke sekolah berdekatan. Mereka juga menitikberatkan aspek pengangkutan awam seperti bas, teksi dan Transit Aliran Ringan (LRT) kerana segelintir daripada mereka tidak gemar untuk memandu dalam kesesakan lalu lintas khususnya bagi mereka yang bekerja di pusat bandar. Selain itu, golongan belia bumiputera juga gemar memilih perumahan yang berdekatan dengan pusat membeli-belah dan rekreasi kerana kebanyakan mereka suka meluangkan masa hujung minggu bersama keluarga di tempat sedemikian. Oleh yang demikian, kemudahan awam dan kemudahan asas ini dianggap melengkapi kehidupan seharian mereka sekali gus menjadikannya aspek penting yang diambil kira dalam pembelian perumahan. Kenyataan ini turut disokong oleh $\mathrm{Wu}$ (2010) yang menjelaskan kriteria pilihan golongan muda dalam membeli rumah 
adalah dari sudut lokasinya yang berdekatan dengan tempat kerja dan berhampiran dengan pelbagai fasiliti seperti pengangkutan awam, pusat membeli belah, bank, restoran dan sebagainya.

\section{Metod Kajian}

Metodologi kajian yang digunakan dapat membantu dalam memastikan kajian dijalankan secara tersusun dan menghasilkan satu keputusan kajian yang terbaik. Terdapat pelbagai metodologi kajian yang boleh digunakan yang bergantung pada jenis kajian yang dijalankan sama ada dalam bidang saintifik, kesusasteraan, sosiologi, teknologi dan sebagainya.

Kajian ini menumpu pada responden yang terdiri daripada golongan belia yang tinggal di sekitar kawasan Batu Kurau, Perak yang berumur di antara 20 tahun - 40 tahun iaitu yang sudah memiliki rumah atau belum memiliki rumah. Soal selidik diedarkan kepada responden dan soalan yang terkandung dalam soal selidik tersebut berbentuk tertutup. Kajian yang dijalankan ini juga memberikan tumpuan terhadap trend demografi responden yang terdiri daripada populasi, bangsa, umur, tahap pendapatan isi rumah, saiz isi rumah, tahap pendidikan dan sebagainya.

Kajian ini dilaksanakan dengan menggunakan kaedah pengumpulan data secara kuantitatif. Tujuan utama kajian kuantitatif digunakan adalah untuk mendapatkan maklum balas secara terus daripada responden dan mendapatkan maklumat yang diperlukan daripada responden dalam menentukan keinginan pemilikan rumah dalam kalangan belia di Batu Kurau, Perak.

Borang soal selidik diedarkan kepada responden dan diisi oleh responden sendiri dengan pengkaji menerangkan serba sedikit kepada responden mengenai tujuan kajian dan cara menjawab soalan soal selidik.

Secara dasarnya, masa yang diambil oleh responden untuk menjawab soal selidik adalah dalam anggaran 10 minit ke-15 minit sahaja. Soal selidik ini terdiri daripada 3 bahagian iaitu Bahagian A) Maklumat latar belakang responden; Bahagian B) Maklumat pemilikan rumah; dan Bahagian C) Masalah yang dihadapi dalam pembelian dan kriteria perumahan.

Pada hakikatnya, maklum balas daripada keseluruhan populasi sebagai responden kajian tidak dapat dilakukan kerana dengan bilangan populasi yang ramai berserta melibatkan kos dan tenaga kerja yang terlalu besar dalam proses pengumpulan data. Disebabkan kekangan tersebut, pembentukan sampel perlu dilakukan. Kaedah persampelan ini dibentuk bagi mendapatkan jumlah yang boleh mewakili keseluruhan populasi kajian. Dalam kajian ini, saiz sampel yang dibuat adalah berdasarkan pada paras keyakinan 90 peratus dan kadar ralat persempelan adalah 0.10. Berdasarkan data jabatan perangkaan 2010, jumlah keseluruhan penduduk Batu Kurau, Perak adalah seramai 26,793 orang. Daripada jumlah tersebut, bilangan penduduk di dalam julat umur 20 tahun -40 tahun ialah seramai 2,369 orang dengan formula seperti berikut:

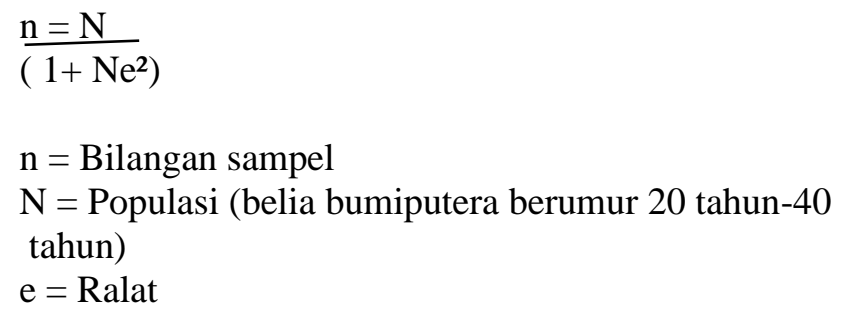

\section{Hasil Kajian}

Dapatan berkaitan faktor yang mempengaruhi pemilikan rumah dalam kalangan belia dianalisis menggunakan analisis deskriptif. Jadual 2 menunjukkan maklum balas responden terhadap setiap item bagi faktor-faktor yang menjadi isu dan permasalahan pemilikan rumah dalam kalangan belia. Dapatan 
menunjukkan kesemua pemboleh ubah adalah signifikan dalam mempengaruhi pemilikan rumah. Faktor-faktor yang paling utama ialah faktor masalah kelayakan mendapatkan pinjaman, faktor bayaran wang pendahuluan yang tinggi, faktor harga rumah yang mampu dimiliki tiada dalam pasaran serta faktor tanggungan anak dan keluarga yang ramai.

Jadual 2: Faktor-Faktor Pemilikan Rumah Dalam Kalangan Belia di Batu Kurau, Perak

\begin{tabular}{lll}
\hline Faktor - Faktor Pemilikan Rumah & Jumlah Skor & $\begin{array}{l}\text { Purata } \\
\text { Skor }\end{array}$ \\
\hline Bayaran wang pendahuluan yang tinggi & 387 & 4.5529 \\
Lokasi tidak sesuai & 235 & 2.7647 \\
Harga rumah yang mampu dimiliki tiada dalam pasaran & 387 & 4.5529 \\
Masalah kelayakan mendapatkan pinjaman & 393 & 4.6235 \\
Mempunyai komitmen kad kredit & 253 & 2.9764 \\
Mempunyai komitmen pinjaman pelajaran & 278 & 3.2706 \\
Tanggungan anak dan keluarga yang ramai & 349 & 4.1059 \\
Gaya hidup mewah & 280 & 3.2941 \\
\hline
\end{tabular}

\section{Perbincangan Kajian}

\section{Masalah Kelayakan Mendapatkan Pinjaman}

Masalah kelayakan mendapatkan pinjaman yang mencatatkan skor purata sebanyak 4.6235. Hal ini kerana, pihak bank tidak akan memberi pinjaman perumahan sebanyak $100 \%$ sebaliknya, jumlah pinjaman maksimum yang diberikan hanya $80 \%$ daripada harga belian rumah. Syarat ini berkait rapat dengan jenis pekerjaan dan tahap pendapatan yang rendah dalam kalangan belia yang menyebabkan golongan ini sering kali menghadapi masalah kelayakan mendapatkan pinjaman perumahan. Walaupun pelbagai rancangan telah dilakukan seperti Perumahan Rakyat 1 Malaysia untuk membantu golongan berpendapatan rendah dan sederhana untuk memiliki rumah, namun golongan ini masih sukar mendapatkan pinjaman perumahan dan jika pinjaman perumahan mereka diluluskan pembiayaan yang diperoleh berada pada tahap yang rendah. Hal ini mempengaruhi kemampuan pemilikan rumah khususnya dalam kalangan belia di Batu Kurau, Perak.

\section{Bayaran Wang Pendahuluan Yang Tinggi}

Faktor bayaran wang pendahuluan yang tinggi mencatatkan purata skor sebanyak 4.5529. Bayaran wang pendahuluan merupakan pembayaran wajib yang perlu dibayar pada peringkat awal untuk pembelian hartanah sama ada dibeli daripada pemaju atau pembelian secara langsung daripada penjual. Pembeli dikehendaki membayar wang pendahuluan minimum sebanyak $10 \%$ untuk pembelian hartanah. Sebagai contoh, sekiranya rumah anda berharga RM500,000, anda akan diminta membayar sekurang-kurangnya RM50,000 sebagai bayaran pendahuluan selaras dengan peruntukan pada Jadual Ketiga Fasal 4 Subseksyen (1) Akta Pemajuan Perumahan (Kawalan dan Pelesenan) 1966 (Akta 118) dan Peraturan-Peraturan yang menyatakan bahawa pembeli rumah hendaklah menjelaskan deposit sebanyak 10 peratus kepada pemaju selepas menandatangani perjanjian jual beli (Akta 118, 2020). Kajian mendapati faktor ini merupakan antara faktor utama golongan belia di Batu Kurau sukar untuk memiliki rumah sendiri.

\section{Harga Rumah Yang Mampu Dimiliki Tiada Dalam Pasaran}

Faktor harga rumah yang mampu dimiliki tiada dalam pasaran mencatatkan skor purata sebanyak 4.5529. Isi rumah tidak mampu untuk membayar harga rumah yang ditawarkan di pasaran sebagai memenuhi keperluan perumahan akan mengalami suatu bentuk keperluan perumahan teras. Berbeza dengan mereka yang mampu yang akan menunjukkan permintaan efektif untuk perumahan. Analisis dan anggaran keperluan perumahan negara semasa dan unjuran masa hadapan perlu membezakan antara keperluan perumahan teras atau permintaan efektif. Hal ini kerana kedua-duanya perlu 
ditangani melalui dasar yang berlainan kerana isi rumah yang berkemampuan memiliki rumah perlu mendapatkan rumah di pasaran perumahan swasta dan bagi mereka yang tidak berkemampuan pula perlu mendapatkan bantuan daripada pihak kerajaan bagi memenuhi keperluan perumahan di pasaran swasta.

Jadual 3. Harga Rumah Yang Dibeli

\begin{tabular}{lll}
\hline Harga rumah yang dibeli & Frekuensi (orang) & Peratusan (\%) \\
\hline RM70,000 - RM99,000 & 1 & 3.0 \\
RM100,000 - RM149,999 & 3 & 9.09 \\
RM150,000 - RM199,000 & 16 & 48.48 \\
RM200,000 - RM249,000 & 8 & 24.2 \\
RM250,000 - RM299,000 & 3 & 9.09 \\
RM300,000 - RM349,000 & 1 & 3.0 \\
Rm400,000 ke atas & 1 & 3.0 \\
Jumlah & 33 & 100 \\
\hline
\end{tabular}

Berdasarkan Jadual 3 iaitu berkenaan harga rumah yang dibeli oleh responden menunjukkan bahawa seramai 16 orang responden (48.48\%) yang membeli rumah pada harga antara RM150,000 hingga RM199,000. Angka ini menunjukkan majoriti penduduk di kawasan Batu Kurau, Perak hanya mampu memiliki rumah pada harga antara RM150, 000 hingga RM199,000. Selain itu, hanya seorang sahaja responden yang membeli rumah berharga RM400,000 ke atas dan seorang responden sahaja yang membeli rumah pada harga RM300,000 hingga RM349,000. Begitu juga bagi rumah yang berharga RM70,000 hingga RM99,000 hanya seorang responden yang mampu membelinya.

Terdapat tiga orang responden yang membeli rumah pada berharga antara RM100,000 hingga RM 149,000 dan seramai lapan orang responden membeli rumah pada harga RM200,000 hingga RM 249,000. Hal ini sepadan dengan jenis pekerjaan golongan belia di Batu Kurau, Perak yang terdiri daripada $16.5 \%$ iaitu seramai 14 orang bekerja sebagai kerani. Jenis pekerjaan merupakan antara indikator utama yang mengukur keupayaan pembelian jenis perumahan seseorang. Hal ini kerana jenis pekerjaan mempunyai perkaitan rapat dengan jumlah pendapatan mereka yang menjadi gambaran kepada keupayaan kewangan mereka dalam memiliki rumah sendiri.

\section{Tanggungan Anak dan Keluarga Yang Ramai}

Analisis faktor yang dilakukan menunjukkan skor purata sebanyak 4.1059 bagi faktor tanggungan anak dan keluarga yang ramai turut menyumbang kepada isu dan permasalahan yang mempengaruhi kemampuan pemilikan rumah dalam kalangan belia. Hal ini kerana memiliki tanggungan anak dan keluarga yang ramai akan menyebabkan jumlah perbelanjaan setiap bulan akan menjadi tinggi sekali gus kemampuan individu untuk membeli aset hartanah semakin berkurang. Selain memiliki tanggungan anak mereka juga perlu menyara ibu bapa dan ahli keluarga lain yang berharap kepada individu tersebut untuk membantu keluarga.

\section{Mempunyai Komitmen Pinjaman Pelajaran dan Kad Kredit}

Komitmen hutang seperti pinjaman pelajaran dan kad kredit merupakan salah satu isu dan permasalahan dalam kemampuan pemilikan rumah dalam kalangan belia. Bagi faktor komitmen pinjaman pelajaran mencatatkan skor purata sebanyak 3.2706. Manakala komitmen kad kredit mencatatkan skor purata sebanyak 2.9764. Perkara ini menunjukkan komitmen hutang responden mempengaruhi kemampuan pemilikan rumah dalam kalangan belia. Hal ini kerana hutang akan memberi kesan kepada kemampuan individu untuk membeli hartanah. Sekiranya jumlah komitmen hutang adalah tinggi, maka pembelian hartanah tidak dapat dilakukan. Bagi menentukan tahap kemampuan pemohon membayar hutang, institusi pemberi pinjaman akan membuat pengiraan kemampuan pinjaman terlebih dahulu menggunakan kaedah kadar Debt Service Ratio (DSR). Sekiranya kadar DSR pemohon rendah, maka pinjaman yang dipohon akan menjadi lebih mudah untuk diluluskan. Hal ini kerana kadar DSR yang rendah menunjukkan pemohon mampu memberi 
komitmen terhadap ansuran bulanan yang perlu dibayar. Sebaliknya jika pengiraan kadar DSR pemohon adalah tinggi, maka pinjaman yang dipohon tidak akan diluluskan kerana kadar DSR yang tinggi membawa maksud pemohon tidak mampu memberi komitmen terhadap pinjaman yang dipohon kerana komitmen sedia ada sudah tinggi untuk ditanggung.

\section{Gaya Hidup Mewah}

Analisis faktor yang dilakukan menunjukkan purata skor bagi gaya hidup mewah adalah 3.2941 yang turut mempengaruhi pemilikan rumah dalam kalangan belia. Hal ini kerana gaya hidup yang mewah menyebabkan peluang untuk membeli rumah pada usia muda tidak tercapai. Sebagai contoh, pembelian barangan mewah seperti kereta import pada usia muda akan menyebabkan individu tersebut akan dibebani oleh hutang pinjaman kereta sekali gus akan meningkatkan komitmen bulanan sehingga menyebabkan mereka tidak mampu untuk memiliki rumah. Selain itu, terdapat juga individu yang menginginkan rumah besar dan cantik sebagai kepuasan hati serta sebagai lambang kejayaannya. Perkara ini tidak akan menjadi masalah kepada individu yang berkemampuan namun bagi yang tidak berkemampuan, gaya hidup mewah ini hanya akan menjerat mereka dikemudian hari.

\section{Lokasi Tidak Sesuai}

Lokasi yang tidak sesuai juga menjadi salah satu isu dan permasalahan pemilikan rumah dalam kalangan belia. Faktor lokasi mencatatkan skor purata sebanyak 2.7647. Hal ini membawa maksud lokasi perumahan yang ditawarkan kepada golongan belia adalah jauh dari tempat kerja dan terletak di kawasan pinggir bandar menjadikan golongan beliau tidak berminat dengan kawasan perumahan yang ditawarkan. Justeru itu lokasi ini tidak sesuai bagi golongan belia untuk membeli rumah.

\section{Kesimpulan}

Kajian ke atas responden dari kalangan belia bumiputera di kawasan Batu Kurau, Perak menunjukkan tahap sebenar kemampuan pemilikan rumah yang hanya mampu membeli harta tanah kediaman yang berharga di bawah RM150,000 seunit. Dengan pembangunan perumahan yang semakin pesat berlaku di kawasan Batu Kurau agak sukar bagi golongan ini memiliki rumah sendiri dengan harga rumah di pasaran yang melambung tinggi. Hal ini disokong oleh Norazmawati (2021a) yang menyatakan bahawa terdapat tiga tekanan perumahan pasca pandemik Covid-19 iaitu lambakan pasaran perumahan, pasaran perumahan merosot pada jangka pendek dan sederhana dan ramalan pasaran perumahan pada masa hadapan. Pemulihan industri perumahan yang cepat dijangkakan akan mengambil masa sehingga 3 tahun selepas pandemik Covid-19 berakhir dengan syarat terdapatnya kerjasama yang padu antara pihak kerajaan dan semua pihak yang berkaitan dalam industri perumahan (Norazmawati, 2021b).

Sekiranya tiada usaha daripada pihak kerajaan untuk membantu golongan sasar ini untuk memiliki rumah sendiri, nescaya ramai anak-anak muda ini akan terus menyewa dan tidak mampu untuk memiliki rumah. Antara cadangan yang boleh membantu usaha kerajaan untuk memastikan dan menggalakkan golongan belia di Batu Kurau, Perak untuk memiliki rumah sendiri ialah dengan menyediakan skim perumahan yang khusus untuk mereka. Selain itu dicadangkan agar pihak kerajaan mewujudkan bank yang khusus untuk urusan perumahan dengan syarat yang lebih mudah dan pihak kerajaan perlu mengawal aktiviti spekulasi harta tanah oleh pihak yang mementingkan keuntungan semata-mata dengan mengetepikan hak dan keperluan golongan belia ini untuk memiliki rumah sendiri. Dengan bantuan dan galakan daripada pihak kerajaan khususnya akan dapat memberi peluang dan ruang yang lebih terbuka untuk golongan belia di Batu Kurau, Perak untuk memiliki rumah sendiri tanpa perlu menyewa di sepanjang hayat mereka. 


\section{Penghargaan}

Penghargaan kepada Mega Jati Academy untuk Geran Industri dengan kod projek: AO2263 untuk penulis di Pusat Pengajian Perumahan, Bangunan dan Perancangan, Universiti Sains Malaysia, Pulau Pinang, Malaysia yang menyokong penyelidikan ini.

\section{Rujukan}

Akta Pemajuan Perumahan (Kawalan dan Pelesenan) 1966 (Akta 118) dan Peraturan-Peraturan. International Law Book Services. Hingga $15^{\text {th }}$ Februari 2020.

Arimah, B.C. (1997). The determinants of housing tenure choice in Ibadan, Nigeria. Urban Studies, $34(1), 105-124$.

Bujang, A. A. (2006). Pemilikan Harta Tanah Kediaman, Satu Kajian Penilaian Ke Atas Pencapaian Matlamat Peraturan Kuota Lot Bumiputra di Daerah Johor Baru. Universiti Malaya.

Hulchanski, J.D. (1995). The concept of housing affordability: six contemporary uses of the housing expenditure-to-income ratio. Housing Studies, 10(4), 471-491.

Jemila, S.H. \& Dietrich, V.R. (2006). Residuals in the Extended Growth Curve Model. Scandinavian Journal of Statistics, 33 (1), 121-138.

Norazmawati M.S. (2007). Kemampuan Pemilikan Rumah Kos Rendah di Kuala Lumpur. PhD Tesis. Pulau Pinang: Universiti Sains Malaysia.

Norazmawati M.S. (2021a). Tekanan Perumahan Pasca Pandemik Covid-19 Terhadap Kemampuan Perumahan. Jurnal Dunia Pengurusan, 3(2), 59-66.

Norazmawati M.S. (2021b). The impact of the Covid-19 Pandemic in Pulau Pinang, in the Context of the Housing Industry. Sumerianz Journal of Social Science, 3(11), 137-141

$\begin{array}{lllll}\text { Pusat Maklumat Harta } & 2010 .\end{array}$ https://napic.jpph.gov.my/portal/ms/web/guest/about-napic

Thalmann, P. (2003). 'House poor' or simply 'poor'? Journal of Housing Economics, 12(4), 291-317.

Wu, F. (2010). Housing Environment Preference of Young Cconsumers in Guangzhou, China: Using the Analytic Hierarchy Process. Property Management, 28(3), 174-192. Retrieved from http://www.emeraldinsight.com/10.1108/02637471011051318

Yates, J. \& Gabriel, M. (2006). Housing Affordability in Australia. Economics. 